\title{
Media Penyuluhan Bahaya Narkoba dengan Teknologi Augmented Reality Berbasis Mobile Android
}

\author{
Mustagfirin $^{1 *}$, Iwan Riyanto ${ }^{2}$ \\ 1,2 Jurusan TEKNIK INFORMATIKA , Fakultas TEKNIK, Universitas Wahid Hasyim \\ Jl. Menoreh Tengah X/22, Sampangan, Semarang 50236. \\ "Email: mustagfirin@unwahas.ac.id
}

\begin{abstract}
Abstrak
Penyalahgunaan narkoba di Indonesia saat ini sangat memprihatinkan, terlihat dengan makin banyaknya pengguna narkoba dari semua kalangan. Hal ini dikarenakan kurangnya informasi dan pengetahuan tentang bahaya penyalahgunaan narkoba. Sedangkan penyampaian informasi dilakukan melalui penyuluhan atau ceramah, diskusi, simulasi tentang bahaya narkoba, film atau media, seminar, pelatihan dan bimbingan kelompok. Dengan semakin pesatnya perkembangan zaman, penyampaian informasi juga dapat memanfaatkan sebuah teknologi, yaitu teknologi Augmented Reality. Augmented reality (AR) adalah jenis teknologi interaktif menggabungkan benda nyata dan virtual yang akan menghasilkan objek $3 D$ yang akan ditampilkan pada layar. Teknologi augmented reality ini dapat diterapkan dalam penyampaian informasi bahaya penyalahgunaan narkoba. Berdasarkan kasus tersebut mendorong penulis untuk melakukan penelitian dengan membuat aplikasi dengan menggunakan metode MDLC yang terdiri dari concept, design, material collecting, assembly, dan testing. Aplikasi nantinya berjalan pada smartphone. Pembangunan aplikasi menggunakan Unity 3D dengan pemanfaatan Augmented Reality Vuforia SDK. Kemudian untuk pembuatan objek 3D menggunakan software Blender. Sedangkan pemodelan aplikasi ini menggunakan metode UML berupa use case diagram, activity diagram, dan sequence diagram. Hasil dari penelitian ini adalah dihasilkannya sebuah aplikasi Augmented Reality Bahaya Narkoba berbasis mobile android.
\end{abstract}

Kata kunci: Augmented Reality, Bahaya Narkoba, Penyalahgunaan Narkoba, Unity 3D, Vuforia SDK.

\section{PENDAHULUAN \\ 1.1 Latar Belakang}

Penyalahgunaan narkoba di Indonesia saat ini sangat memprihatinkan, terlihat dengan makin banyaknya pengguna narkoba dari semua kalangan. Namun yang lebih memprihatinkan penyalahgunaan narkoba saat ini justru banyak dilakukan oleh kalangan remaja (BNN,2018). Banyaknya penyalahgunaan narkoba yang dilakukan oleh remaja dikarenakan pada masa remaja sedang mengalami keadaan emosional yang labil dan mempunyai keinginan besar untuk mencoba serta mudah terpengaruh oleh lingkungan dan teman sebaya tanpa mengetahui efek yang ditimbulkan akan penyalahgunaan narkoba.

World drugs repot dari United Nation Office Drugs and Crime (UNODC) menyatakan terdapat 167 sampai 315 juta $(4,8$ persen sampai 5,2 persen) orang penyalahgunaan dari populasi penduduk dunia yang berumur 15 sampai 64 tahun yang menggunakan narkoba minimal sekali dalam setahun di tahun 2013. Berdasarkan hasil penelitian Badan Narkotika Nasional (BNN) bekerjasama dengan Pusat Penelitian Kesehatan Universitas Indonesia Tahun 2017 tentang Survei Nasional Penyalahgunaan Narkoba, didapat bahwa angka proyeksi penyalahguna narkoba di Indonesia mencapai 1,77 persen atau 3.367.154 orang yang pernah pakai narkoba dalam setahun terakhir (current users) pada kelompok usia 10 sampai 59 tahun. Berdasarkan hasil survei pada populasi umum, penyalahgunaan narkoba pada generasi muda masih lebih tinggi daripada kelompok yang lebih tua. Usia awal (12 sampai 14 tahun) hingga akhir (15 sampai 17 tahun) sangat beresiko tinggi untuk memulai menggunakan narkoba, dan peningkatan penyalahgunaan tertingginya terjadi pada remaja berusia 18 sampai 25 tahun. Survei BNN menjelaskan, secara keseluruhan, angka prevalensi pelajar dan mahasiswa yang pakai narkoba satu tahun terakhir sebesar 3,2 
persen, atau setara 2.297.492 orang dengan angka prevalensi untuk pelajar SMP 4,8 persen, pelajar SMA 6,4 persen dan mahasiswa 6 persen (BNN, 2018).

Kecenderungan banyaknya jumlah pengguna dengan korban penyalahgunaan narkoba menunjukkan suatu fakta bahwa narkoba merupakan ancaman yang sangat serius, karena pada kenyataannya banyak kalangan pelajar adalah pengguna narkoba (Ismail, 2017). Faktor penyebab pelajar menggunakan narkoba diantaranya karena rasa ingin tahu yang besar dan adanya pengaruh teman sebaya serta pengaruh dari lingkungan keluarga yang kurang harmonis. Ketersediaan dan kemudahan memperoleh narkoba juga disebut sebagai pemicu seseorang menjadi pecandu narkoba.

Kebanyakan remaja menggunakan narkoba juga karena kurangnya pengetahuan akan narkoba, dampak dan resiko, atau pengetahuan yang didapat minim dan dari sumber yang tidak terpercaya. Kurangnya pengetahuan dan salahnya informasi justru akan lebih meningkatkan rasa penasaran seseorang. Salah satu cara yang dilakukan sebagai pendekatan untuk menanggulangi masalah agar narkoba tidak semakin mengakar dengan penyampaian informasi melalui penyuluhan atau ceramah, diskusi, simulasi tentang bahaya narkoba, film atau media digital, seminar, pelatihan dan bimbingan kelompok.

Melalui media digital yang berkembang sangat pesat saat ini, masalah tersebut seharusnya bisa dihindari, setidaknya bisa diminimalisasi. Media digital dalam hal ini yaitu media elektronik seperti TV, radio, komputer, smartphone, yang terkomputerisasi (diproses melalui kompter) dan dipublish dalam bentuk gambar statis elektronik (poster digital), gambar bergerak (video, animasi, motion graphic), aplikasi interaktif (website, apps, media interaktif), serta augmented reality (AR) dan virtual reality (VR). Augmented Reality merupakan salah satu teknologi yang berkembang di dunia, menggabungkan benda maya dua dimensi ataupun tiga dimensi ke dalam sebuah lingkungan nyata tiga dimensi lalu memproyeksikan benda-benda maya tersebut dalam waktu nyata (Furht, 2011). Teknologi Augmented Reality juga dapat dikombinasikan dengan perangkat Mobile Android.

Menurut Kadir (2013), Android adalah suatu sistem operasi sebuah perangkat bergerak yang dewasa ini sangat terkenal. Penggunaan mobile Android yang mudah dan praktis banyak digemari oleh semua kalangan. Dengan kombinasi mobile Android dengan teknologi Augmented Reality akan menampilkan simulasi bentuk tiga dimensi yang nyata dalam sebuah perangkat mobile sehingga tidak akan merasa bosan dalam memahami dan mengaplikasikannya ke dalam keadaan sebenarnya.

Dari latar belakang ini peneliti tertarik untuk menambah pengetahuan dan pemahaman mengenai bahaya narkoba dengan media penyuluhan Augmented Reality tentang bahaya narkoba dengan menarik dan inovatif berbasis mobile Android.

\section{TINJAUAN PUSTAKA \\ 2.3 Narkoba}

Narkoba adalah singkatan dari narkotika dan obat atau bahan berbahaya. Selain Narkoba, istilah lain yang diperkenalkan khusunya oleh Kementrian Kesehatan Republik Indonesia adalah Napza yang merupakan singkatan dari narkotika, psikotropika, dan zat adiktif (Rois, 2018 ).

Semua istilah ini, baik Narkoba ataupun Napza mengacu pada kelompok senyawa yang umumnya memiliki risiko kecanduan bagi penggunanya.Menurut pakar kesehatan, Narkoba sebenarnya adalah senyawa-senyawa psikotropika yang biasa dipakai untuk membius pasien saat hendak dioperasi atau obat-obatan untuk penyakit tertentu. Namun kini persepsi itu disalah artikan akibat pemakaian di luar peruntukan dan dosis yang semestinya.

\subsection{Augmented Reality}

Pada dasarnya, augmented reality mengkombinasikan dunia nyata dengan komputer grafis, menyediakan interaksi dengan objek maya secara real-time, dapat membawa objek maya pada dunia nyata, mengenali gambar atau objek, dan menyediakan konteks atau data dengan real-time dengan menambahkan nilai dengan informasi virtual. Visualisasi objek dunia maya pada dunia nyata memungkinkan dapat menutup objek dunia 
nyata atau pula mengubah perspektif dunia nyata itu sendiri. Misalnya augmented reality dapat menutup meja dengan sebuah gajah besar. (Furht,2011).

\subsection{Vuforia SDK}

Vuforia merupakan software untuk Augmented Reality, yang menggunakan sumber yang konsisten mengenai computer vision yang fokus pada image recognition. Vuforia mempunyai banyak fitur-fitur dan kemampuan, yang dapat membantu pengembang untuk mewujudkan pemikiran mereka tanpa adanya batas secara teknikal (Adami Zulham dan Budihartanti., 2016).

\subsection{Unity 3D}

Unity merupakan suatu aplikasi yang digunakan untuk mengembangkan game multi platform yang didesain untuk mudah digunakan. Unity itu bagus dan penuh perpaduan dengan aplikasi yang profesional. Editor pada Unity dibuat dengan user interface yang sederhana. Editor ini dibuat setelah ribuan jam dihabiskan untuk membuatnya menjadi nomor satu dalam urutan ranking teratas untuk editor game. Grafis pada unity dibuat dengan grafis tingkat tinggi untuk OpenGL dan direct $X$. Unity mendukung semua format file, terutamanya format umum seperti semua format dari art applications. Unity cocok dengan versi 64-bit dan dapat beroperasi pada Mac OS dan windows dan dapat menghasilkan Game untuk Mac, Windows, Wii, iPhone, iPad dan Android. Unity secara rinci dapat digunakan untuk membuat video game 3D, real time animasi 3D dan visualisasi arsitektur dan isi serupa yang interaktif lainnya ( Roedavan, 2016).

\subsection{Android}

Android secara sederhana bisa diartikan sebagai sebuah software yang digunakan pada perangkat mobile yang mencakup sistem operasi, middleware, dan aplikasi kunci yang dirilis oleh Google. Sehingga android mencakup keseluruhan aplikasi, mulai dari sistem operasi sampai pada pengembangan aplikasi itu sendiri. Pengembangan aplikasi pada platform android ini menggunakan dasar bahasa pemrograman Java. Tapi secara sempit, Android biasanya mengacu pada sistem operasinya saja (EMS, 2015).

\section{METODE PENELITIAN}

Pada penelitian ini, metode yang diusulkan yaitu menggunakan metode Multimedia Development Lifecycle (MDLC). Menurut Sutopo (2003) MDLC atau pengembangan multimedia adalah penggunaan dan perpaduan gambar, video dan suara dalam multimedia yang menarik maupun menggugah minat belajar peserta didik atau siswa. Multimedia juga mampu memudahkan penyampaian materi-materi tertentu kepada siswa dibandingkan dengan cara penyampaian materi lainnya.

Tahapan pengembangan dalam Multimedia Development Life Cycle (MDLC) (Sutopo, 2003) yang terlihat pada gambar 1.

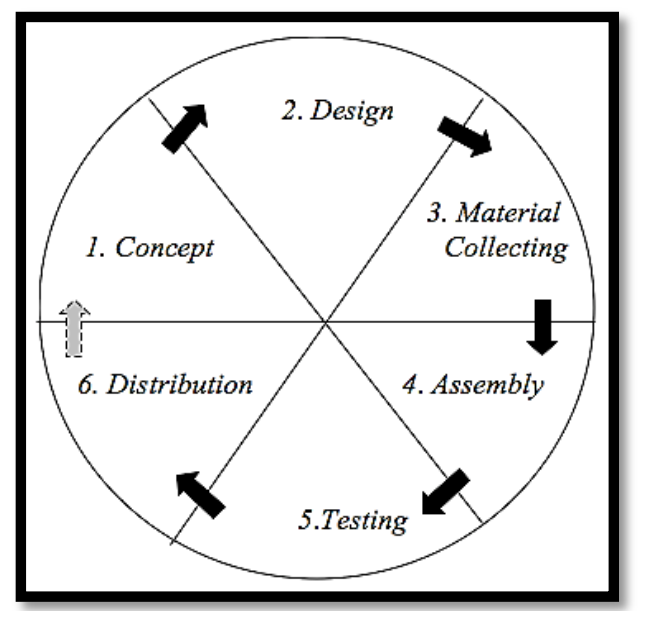

\section{Gambar 1. Multimedia Development Life} Cycle (Sutopo, 2003)

\section{Concept}

Tahap Concept (pengonsepan) adalah tahap untuk menentukan tujuan dan siapa pengguna program (identifikasi audiens). Tujuan dan pengguna akhir program berpengaruh pada nuansa multimedia sebagai pencerminan dari identitas organisasi yang menginginkan informasi sampai pada pengguna akhir. Karakteristik pengguna termasuk kemampuan pengguna juga perlu dipertimbangkan karena dapat mempengaruhi pembuatan desain.

\section{Design}

Design (perancangan) adalah tahap pembuatan spesifikasi mengenai arsitektur program, gaya, tampilan, dan kebutuhan 
material atau bahan untuk program. Spesifikasi dibuat serinci mungkin sehingga pada tahap berikutnya, yaitu material collecting dan assembly, pengambilan keputusan baru tidak diperlukan lagi, cukup menggunakan keputusan yang sudah ditentukan pada tahap ini. Meskipun demikian, pada praktiknya, proyek pada tahap awal masih akan sering mengalami penambahan bahan atau pengurangan bagian aplikasi, atau perubahan-perubahan lain.

\section{Material Collecting}

Material collecting adalah tahap pengumpulan bahan yang sesuai dengan kebutuhan yang dikerjakan. Bahan-bahan tersebut, antara lain gambar clip art, foto, animasi, video, audio, dan lain-lain yang dapat diperoleh secara gratis atau dengan pemesanan kepada pihak lain sesuai dengan rancangannya. Tahap ini dapat dikerjakan secara paralel dengan tahap assembly. Namun, pada beberapa kasus, tahap material collecting dan tahap assembly akan dikerjakan secara liniear dan tidak paralel.

\section{Assembly}

Tahap assembly adalah tahap pembuatan semua objek atau bahan multimedia. Pembuatan aplikasi didasarkan pada tahap design, seperti storyboard, bagan alir, dan struktur navigasi. Tahap ini biasanya menggunakan perangkat lunak sebagai alat pembuatnya seperti unity $3 \mathrm{~d}$ atau yanglainnya.

\section{Testing}

Tahap testing (pengujian) dilakukan setelah menyelesaikan tahap pembuatan (assembly) dengan menjalankan aplikasi atau program dan melihatnya apakah ada kesalahan atau tidak. Tahap pertama pada tahap ini disebut tahap pengujian alpha (alpha test) yang pengujiannya dilakukan oleh pembuat atau lingkungan pembuatnya sendiri. Setelah lolos dari pengujian beta yang melibatkanpengguna akhir akan dilakukan.

\section{Distribution}

Pada tahap ini, aplikasi akan disimpan dalam suatu penyimpanan. Jika media penyimpanan tidak cukup untuk menampung aplikasinya, kompresi terhadap aplikasi tersebut akan dilakukan. Tahap ini juga dapat disebut tahap evaluasi untuk pengembangan produk yang sudah jadi supaya menjadi lebih baik. Hasil evaluasi ini dapat digunakan sebagai masukan untuk tahap concept pada produk selanjutnya.

\section{HASIL DAN PEMBAHASAN \\ 3.1 Hasil Aplikasi}

Pada bab ini membahas tentang hasil pembuatan Aplikasi AR Bahaya Narkoba. Berikut tampilannya :

\subsubsection{Halaman pembuka (splash screen)}

Pada halaman pembuka (splash screen) merupakan tampilan awal yang menampilkan logo stop narkoba halaman ini akan tampil hanya beberapa detik dan selanjutnya akan dialihkan ke menu utama seperti yang terlihat pada gambar 2 .

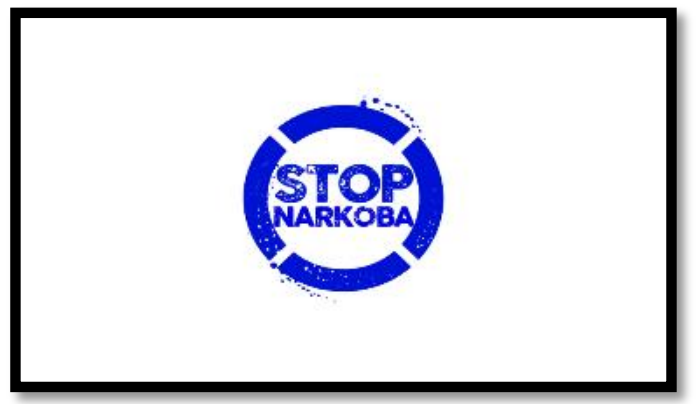

Gambar 2. Halaman Pembuka

\subsubsection{Halaman menu utama ( main menu)}

Pada halaman menu utama terdapat beberapa menu antara lain (dari kiri ke kanan) Menu Website BNN, Menu Mulai, Menu Petunjuk, Menu Tentang, Menu Keluar, dan Menu Website Unwahas tampilan keseluruhan bisa dilihat pada gambar 3 .

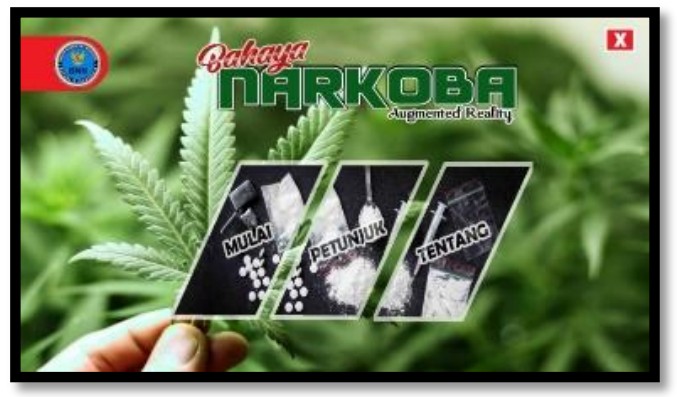

Gambar 3. Halaman Menu Utama 


\subsubsection{Halaman menuju website $\mathrm{BNN}$}

Pada halaman menu website BNN pengguna secara otomatis akan di alihkan ke website BNN seperti terlihat pada gambar 4.

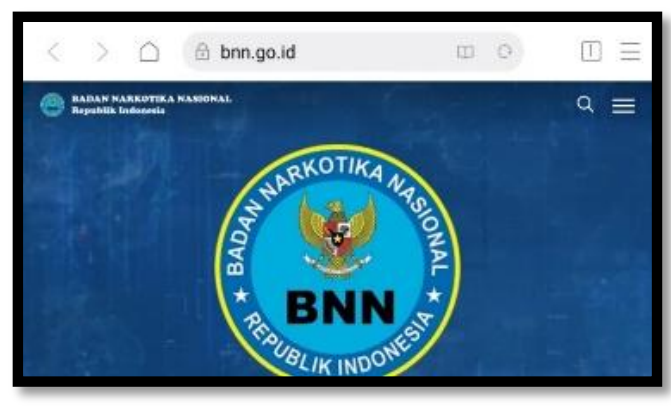

\section{Gambar 4. Menuju Alamat bnn.go.id}

\subsubsection{Halaman menu mulai (menu augmented} reality)

Pada halaman menu mulai merupakan menu yang menyajikan fitur augmented reality dimana device akan membuka kamera dan mecari marker untuk menampilkan sebuah objek tiga dimensi seperti gambar 5 .

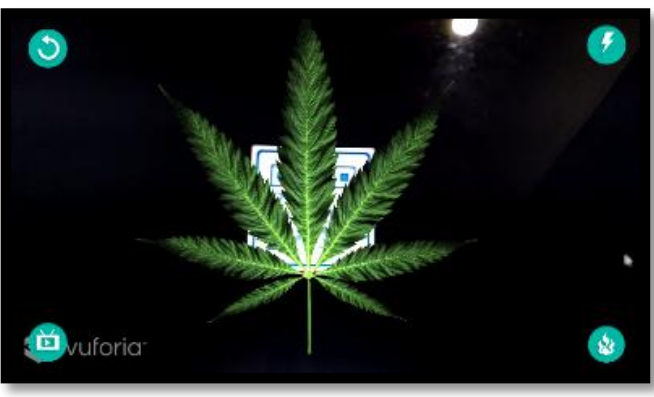

\section{Gambar 5. Objek Tiga Dimensi Ganja}

\subsubsection{Halaman menu petunjuk}

Pada halaman menu petunjuk terdapat petunjuk cara pemakain dari aplikasi ini salah satunya adalah cara memperbesar objek dengan menempelkan kedua jari dan merentangkannya berlawanan arah lebih jelasnya lihat pada gambar 6.

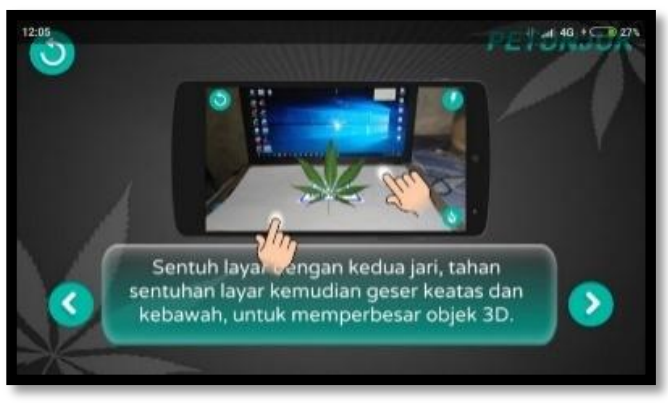

\section{Gambar 6. Petunjuk Memperbesar Objek Tiga Dimensi}

\subsubsection{Halaman menu tentang}

Pada halaman menu tentang berisi tentang informasi - informasi yang ada pada aplikasi ini antara lain tujuan dibuatnya aplikasi, pembuat aplikasi, sumber video pada aplikasi, berikut adalah salah satu isi dari menu tentang yang terlihat pada gambar 7 .

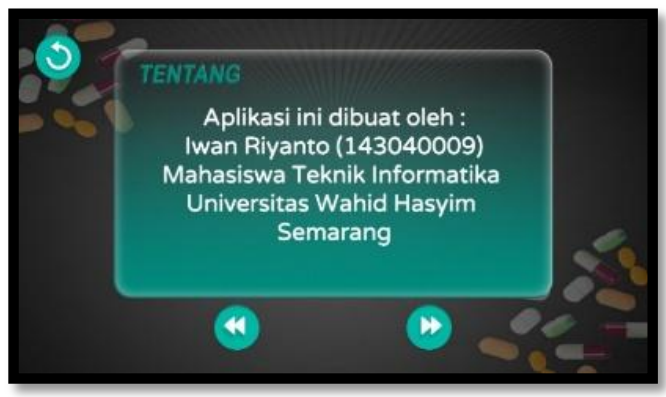

Gambar 7. Informasi Pembuat Aplikasi

\subsubsection{Halaman menu keluar}

Pada halaman menu keluar muncul suatu peringatan atau pop-up "apakah anda ingin keluar aplikasi?" dan muncul dua pilihan ya dan tidak, apabila ya ditekan maka aplikasi akan tertutup, apabila tidak maka menu akan kembali ke menu utama lebih jelasnya lagi lihat pada gambar 8 .

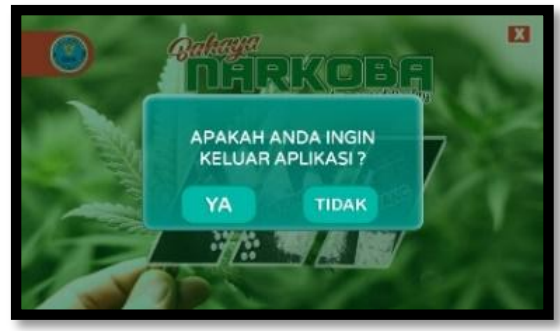

Gambar 8. Tampilan Menu Keluar 


\subsubsection{Halaman menu website Unwahas}

Pada halaman menu website Unwahas pengguna secara otomatis akan di alihkan ke browser bawaan dari smartphone, menuju alamat url http://unwahas.ac.id.Terlihat pada gambar 9.

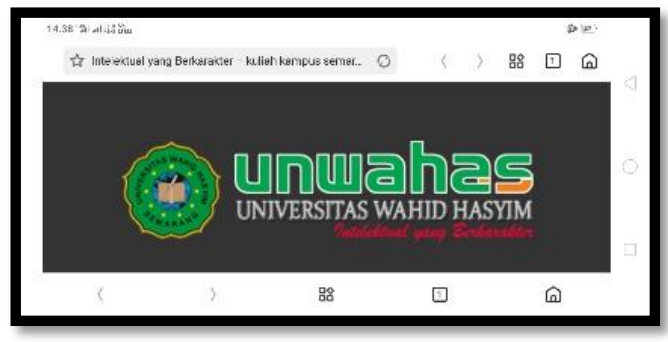

\section{Gambar 9. Menuju alamat unwahas.ac.id}

\subsection{Hasil Pengujian}

Hasil uji coba yang telah dilakukan dengan alpha test pada Aplikasi "AR Bahaya Narkoba" yaitu terlihat pada pengujian pengujian sebagai berikut.

Tabel 1. Pengujian Menu Utama

\begin{tabular}{|c|c|c|c|}
\hline \multicolumn{4}{|c|}{ Menu Utama } \\
\hline Fungsi & Button & Keterangan & Kesimpulan \\
\hline $\begin{array}{l}\text { Merupak } \\
\text { an menu } \\
\text { utama } \\
\text { dari } \\
\text { aplikasi } \\
\text { ini, } \\
\text { dimana } \\
\text { menu ini } \\
\text { menamp } \\
\text { ilkan } \\
\text { beberapa } \\
\text { pilihan } \\
\text { menu- } \\
\text { menu } \\
\text { yang } \\
\text { lain. }\end{array}$ & $\begin{array}{l}\text { 1. Logo } \\
\text { BNN } \\
\text { 2. Mulai } \\
\text { 3. Petunj } \\
\text { uk } \\
\text { 4. Tentan } \\
\text { g } \\
\text { 5. Logo } \\
\text { Unwah } \\
\text { as } \\
\text { 6. Silang } \\
\text { (X) }\end{array}$ & $\begin{array}{l}\text { 1. Menampil } \\
\text { kan Menu } \\
\text { Website } \\
\text { BNN } \\
\text { 2. Menampil } \\
\text { kan Menu } \\
\text { Mulai } \\
\text { 3. Menampil } \\
\text { kan Menu } \\
\text { Petunjuk } \\
\text { 4. Menampil } \\
\text { kan Menu } \\
\text { Tentang } \\
\text { 5. Menampil } \\
\text { kan Menu } \\
\text { Website } \\
\text { Unwaha } \\
\text { 6. Menampil } \\
\text { kan Menu } \\
\text { Keluar }\end{array}$ & $\begin{array}{l}\text { 1. Berhasil } \\
\text { 2. Berhasil } \\
\text { 3. Berhasil } \\
\text { 4. Berhasil } \\
\text { 5. Berhasil } \\
\text { 6. Berhasil }\end{array}$ \\
\hline
\end{tabular}

\subsubsection{Pengujian blackbox}

Pada pengujian ini dilakukan untuk mengetes menu-menu yang ada pada aplikasi "AR Bahaya Narkoba" antara lain menu splash screen, menu utama, menu website $\mathrm{BNN}$, menu mulai, menu petunjuk, menu tentang, menu website Unwahas, dan menu keluar. Pada kesimpulan pengujian ini rata-rata keberhasilan fungsi menu berfungsi dengan baik, seperti yang ditunjukkan pada tabel 1 .

\subsubsection{Pengujian marker}

Pada pengujian marker dilakukakan beberapa uji coba lainnya antara lain uji coba sudut dan jarak antara kamera dengan marker, uji coba dengan menutupi area marker, uji coba perbedaan ukuran marker. Berikut adalah contoh pengujian sudut dan jarak antara kamera dengan marker terlihat pada gambar 10.

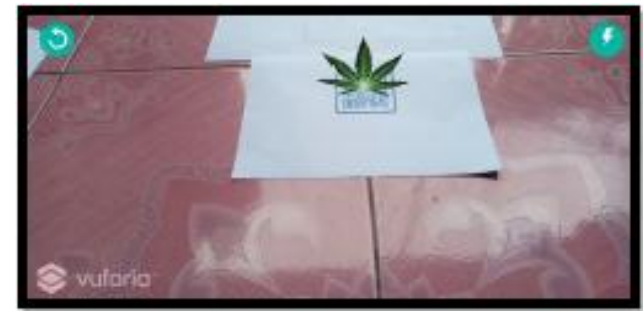

Gambar 10. Sudut 60 Derajat dengan Jarak $41 \mathrm{~cm}$ sampai $50 \mathrm{~cm}$

\subsubsection{Pengujian pada perangkat mobile}

Pada uji coba ini akan dilakukan pada fungsi dan tampilan aplikasi terhadap beberapa Smartphone dengan spesifikasi yang berbeda, adapun pengujian yang digunakan penulis menggunakan Smartphone merk Oppo A5S, Xiaomi Redmi 5A, Oppo A37, Xiaomi Redmi $3 S$.

Tabel 2. Uji Coba Fungsi dan Tampilan

\begin{tabular}{llll}
\hline Merk & Resolusi & Kamera & Hasil \\
\hline Oppo & 6,2 Inch & Blkng: & Fungsi : \\
A5S & $1520 \times 720$ & 13 MP & Normal \\
& Piksel & 2 MP & Tampilan: \\
& & Dpn : & Melebar \\
& & $8 \mathrm{MP}$ & \\
\hline Xiaomi & 5.0 Inch, & Blkng: & Fungsi : \\
redmi & 1280x720 & 13 MP & Normal \\
$5 A$ & piksel & Dpn: & Tmpilan: \\
& & $5 \mathrm{MP}$ & Normal \\
\hline Oppo & 5,9 Inch & Blkng: & Fungsi : \\
A37 & $1080 \times 2160$ & $16 \mathrm{MP}$ & Normal \\
& piksel & Dpn: & Tampilan: \\
& & $5 \mathrm{MP}$ & Normal \\
\hline Xiaomi & 5.0 Inch, & Blkng: & Fungsi : \\
Redmi & $1280 \times 720$ & $13 \mathrm{MP}$ & Normal \\
$3 S$ & piksel & Dpn: & Tmpilan: \\
& & $5 \mathrm{MP}$ & Normal
\end{tabular}


Aplikasi ini mendukung untuk versi Smartphone yang ber OS minimal Android versi 5.0 Lollipop dan juga memiliki Ram 2 GB, seperti yang ditunjukkan pada tabel 2 .

\section{KESIMPULAN}

Penelitian ini menghasilkan sebuah aplikasi Media Penyuluhan Bahaya Narkoba Dengan Teknologi Augmented Reality Berbasis Mobile Android yang diberi nama aplikasi "AR Bahaya Narkoba", sebagai media belajar dan media penyuluhan untuk mempermudah masyarakat khususnya remaja dalam mengenal bahaya penyalahgunaan Narkoba.

Hasil pengujian pada aplikasi menunjukkan bahwa setiap proses pada aplikasi AR ini berjalan dengan baik dan sesuai dengan rancangan. Hasil pengujian marker sudut $\left(0^{\circ}\right.$, $30^{\circ}, 60^{\circ}$, dan $90^{\circ}$ ), jarak (0 cm sampai $50 \mathrm{~cm}$ antara kamera dan marker ), menutup sebagian marker (tertutup $25 \%$ bagian, $50 \%$ bagian, $75 \%$ bagian), dan perbedaan ukuran marker (6x6, 12x12, 18x18, dan 20x20) menunjukkan bahwa beberapa kondisi dapat mempengaruhi proses pendeteksian marker, dan juga spesifikasi device yang digunakan juga dapat mempengaruhi tampilan dan kecepatan atau kelancaran dalam menjalankan aplikasi ini.

\section{DAFTAR PUSTAKA}

Adami, F,Z., Budihartanti, C., 2016, Penerapan Teknologi Augmented Reality Pada Media Pembelajaran Sistem Pencernaan Berbasis Android, Jurnal Teknik Komputer Amik BSI, Volume II No.1.

BNN, 2018, Executive Summary Survei Penyalahgunaan Dan Peredaran Gelap Narkoba Tahun 2018, Hasil Penelitian BNN, Hal 14.

EMS, Tim., 2015, Pemrograman Android Dalam Sehari, PT Elex Media Komputindo, Jakarta.

Furht, Borko., 2011, Handbook of Augmented Reality, florida, Springer.Kadir, A., 2013, Pemrograman Aplikasi Android, Andi, Yogyakarta.

Ismail, W., 2017, Teori Biologi Tentang Perilaku Penyalahgunaan Narkoba, Jurnal Biotek Volume 5 no 1, Hal 127 43.

Kadir, A., 2013, Pemrograman Aplikasi Android, Andi, Yogyakarta.
Roedavan, R., 2016, Unity Tutorial Game Engine, Informatika Bandung, Bandung.

Rois, N., 2019, Jihad Melawan Narkoba Strategi Pendidikan Pencegahan Penyalahgunaan Narkoba Bagi Generasi Melenial, Semarang.

Sutopo, A.H., 2012, Teknologi Informasi dan Komunikasi dalam Pendidikan, Jilid 1, Edisi Pertama, Graha Ilmu, Yogyakarta.

World Drug Report, 2015,
http://www.unodc.org.

